\section{Transpiration Current in Horsetails}

THE xylem system of Equisetum appears so inadequate for the vigorous transpiration maintained, which may be twice as great as in the sunflower ${ }^{1}$, that the suggestion has been made that water travels in the canal-system of the stem ${ }^{2}$.

The following observations support this idea. I have constantly found, in the fertile shoots of $E$. maximum, that both carinal and vallecular canals and the large central lumen of the stem are filled with water under pressure. If an incision is made at the top of an internode a strong spurt of water escapes.

This liquid has the following characteristics: $p \mathrm{H}$ $6 \cdot 6$, optically inactive, no reducing sugar present, no nitrate or nitrite, no amino acids, a trace of sulphate and a considerable amount of phosphate present. Evaporation leaves a fine, amorphous deposit, insoluble in ether.

When sporophore shoots are cut and left in water, even in a covered vessel, the upper internodes collapse laterally. On making an incision now there is a sharp intake of air, and the walls of the stem again expand. Transpirational loss being excluded by the conditions and direct leakage barred by the Casparian bands, there would seem to be a reversible secretion into these cavities from the surrounding parenchyma.

Similar observations have been made on $E$. hiemale. In both species observation with the binocular microscope shows the vallecular canals to be lined with turgid cells, here and there protruding like tyloses. Each end of a canal section and of an internodal lumen is covered with protruding, vesicular cells of secretory appearance, only distinguishable in living material. The pith lumen is lined with several layers of thin-walled cells, partly turgid, partly collapsed.

The reversed action after cutting, and the resorption of the secreted water, can only be due to the disappearance of the exudation pressure which originated from the roots. The phenomenon is an interesting complement to the development of a centripetal secretion pressure in normal roots and illustrates the upward extension of physiological root conditions in pteridophytic stems with typical secondary endodermis.

University College,

R. C. McLean.

Cardiff.

June 6.

${ }^{1}$ Dosdall, Plant World, 22, 1, 29; 1919.

' Westermaier, Sitzber. Akad. Wissenschaften, 1105; 1884.

\section{Hatching Experiments on the Potato Eelworm (Heterodera schachtii)}

DURING the course of our research on the potato eelworm (H. schachtii) we have established the fact that the root excretion of potatoes growing in recently sterilised soil does not possess the power of inducing hatching of eelworm eggs in the normal manner. In other words, we have found that when eelworm cysts are added to sterilised soil, the hatching of the eggs in these cysts does not commence for a considerable time afterwards although potatoes are growing in the soil. The period elapsing before hatching commences is greatest in very recently sterilised soil and gradually becomes less according as the interval between sterilisation and planting time is increased. This has been proved in the laboratory by hatching experiments (with large numbers of cysts) in which leachings from soil sterilised at different times and growing potatoes have been used. The effect of this delayed hatching is showing up very markedly in pot experiments. From our research it is obvious that, where hatching is delayed, the plants get a chance of making some growth and establishing a good root system before attack by the newly hatched larvæ. The onset of eelworm attack only when a good root system has been established does not seem to have much effect on the further growth or productivity of the plants.

In view of what we have found with sterilised soil, it appears reasonable to suggest that a somewhat similar condition of affairs may sometimes obtain in the field, where, due to one cause or another, plants make some growth and establish a good root system before the onset of eelworm attack. It appears that if hatching is delayed for even a short period after the plants commence to grow, the obvious symptoms of potato sickness do not develop to any extent.

\section{J. Carroll. \\ E. McMaHon.}

Department of Agricultural Zoology, University College,

Dublin.

June 7.

\section{Second Occurrence of the Whale-Shark (Rhineodon typus) in South Africa}

Is April 1828 the first known specimen of the whale-shark was harpooned in Table Bay, and was described by Dr. Andrew Smith. Since then no other specimen had been reported from South African waters until one came ashore at Easter this year. It was found stranded on the sands at Kommetje Bay (on the west side of the Cape Peninsula) on April 2, but unfortunately was not reported to the Museum until three weeks later. The total length was 20 feet. Most of the skin of the upper half of the body, and also the head and fins were saved, from which it will be possible to investigate certain anatomical features which hitherto have been unknown or in need of verification. A description of these will appear later in the Annals of this Museum.

K. H. Barnard.

South African Museum, Cape Town. May 16.

\section{The Australian Oyster}

IN an abstract of my paper entitled "The Life History of the Australian Oyster, Ostrea commercialis"' an error was made in referring to the tem. perature of the water when oysters spawned at Port Macquarie, New South Wales. The temperature of $72^{\circ}-76^{\circ} \mathrm{F}$., given in the abstract as the spawning temperature, refers to that which prevailed for the most part during the six weeks prior to spawning. When the oysters actually spawned, the temperature of the water in contact with them was $68^{\circ} \mathrm{F}$.; the water was two feet deep and the surface temperature was $70^{\circ} \mathrm{E}$.

T. C. Roughiey.

Technological Museum,

Harris Street, Sydney. April 27.

1 Nature, 133, 332, March 3, 1934. 